\title{
Detection of Begomovirus in Chilli and Tomato Plants Using Functionalized Gold Nanoparticles Authors: Lavanya. R and Arun. V
}

\section{Lavanya Ramesh}

Sri Ramachandra Institute of Higher Education and Research

Arun Viswanathan ( $\square$ arun.v@sriramachandra.edu.in )

Sri Ramachandra Medical College and Research Institute: Sri Ramachandra Institute of Higher Education and Research https://orcid.org/0000-0003-3718-4520

\section{Research}

Keywords: Begomovirus, Gold nanoparticles, AuNP assay, Viral detection, Polymerase chain reaction

Posted Date: January 15th, 2021

DOI: https://doi.org/10.21203/rs.3.rs-145079/v1

License: (c) (i) This work is licensed under a Creative Commons Attribution 4.0 International License. Read Full License 


\section{Abstract}

Begomoviruses are a major class of Geminiviruses that affects most dicotyledonous plants and causes heavy economic losses to farmers. Early detection of begomovirus is essential to control the spread of the disease and prevent loss. Many available detection methods like ELISA, immunosorbent electron microscopy, PCR or qPCR require expertise in handling sophisticated instruments, complex data interpretation and costlier chemicals, enzymes or antibodies. Hence there is a need for a simpler detection method, here we report the development of a visual detection method based on functionalized gold nanoparticles (AuNP probe assay). The assay was able to detect upto $500 \mathrm{ag} / \mu \mathrm{l}$ of begomoviral DNA (pTZCCPp3, a clone carrying partial coat protein gene) suspended in MilliQ water. Screening of chilli plants for begomoviral infection by PCR (Deng primers) and AuNP assay showed that AuNP assay (77.7\%) was better than PCR (49.4\%). The AuNP assay with clccpi1 probe was able to detect begomoviral infection in chilli, tomato, common bean, green gram and black gram plants which proved the utility and versatility of the AuNP assay. The specificity of the assay was demonstrated by testing with total DNA from different plants that are not affected by begomoviruses.

\section{Introduction}

Plant pathogens and pests are one of the major factors that limit crop productivity. Infection could be detected easily by visual inspection if the symptoms are clearly characteristic for the disease. However many factors play a major role in identification of infection like viral strain, cultivar, time of infection and other environmental factors (1). Geminiviridae and Potyviridae are the two largest families that constitute important plant viruses, which are highly devastating phytopathogens worldwide $(2,3)$. The family Geminiviridae was established in 1978 (4) and consists of 9 genera: Nine genera - Becurtovirus, Capulavirus, Curtovirus, Eragrovirus, Grablovirus, Mastrevirus, Topocuvirus, Turncurtovirus [Monopartite genome] and Begomovirus [Bipartite genome] (5-7). The genetic material of geminiviruses is ssDNA and have either a monopartite (DNA-A) or bipartite (DNA-A and DNA-B) genome. Of the many geminiviruses infecting economically important crops, begomoviruses are one of the most destructive viruses and are transmitted by whitefly vector Bemisia tabaci (8-10).

Capsicum annuum (Chilli) and Solanum lycopersicum (Tomato) plants belong to the family Solanaceae and are grown in tropical countries. It is a family of flowering plants, consisting of many important crops like potatoes, tomatoes, peppers, tobacco, petunia and other crops of regional significance $(11,12)$. Plants belonging to the Solanaceae family are heavily affected by viruses and begomoviruses are the major pathogen $(8,13-16)$. Begomovirus symptoms in plants range from symptomless to different degrees of stunting and curling, distortion, mosaic, mottling, vein yellowing of leaves, flower abortion, small and unmarketable fruits (17). India is one of the top producers of chilli and tomato in the world and are cultivated across the country throughout the year (18). Begomoviral infection has been reported in different states of India in chilli and tomato plants and were shown to cause severe losses (19).

Begomovirus infecting pepper (chilli) and tomato plants have narrow host ranges and were shown to 
infect plants of other families, e.g., Fabaceae [common bean and soybean (Glycine max)] and Cucurbitaceae $(20,21)$.

One of the basic requirements for the elimination and spread of viruses is detection of the presence of viruses at the earliest possible stage in plants (22). Many methods are available for the detection of plant viruses which could be classified into protein-based methods (immunotechniques) or nucleic acid-based methods (molecular methods). The various immunotechniques include enzyme linked immunosorbent assay (ELISA) (23-25), immunoblotting (26), immunosorbent electron microscopy $(27,28)$ and precipitin tests (29). These methods rely on specific interaction of antibody (monoclonal or polyclonal) with viral antigens (coat protein) and hence are prone for false negativity at low viral titres. The limitations of these methods also include cross-reactivity with similar antigens resulting in false positive results. The production of antibodies is tedious, expensive and requires expertise.

Molecular methods like PCR (30-33), Nucleic Acid Spot Hybridization (NASH) assay (34-40) depend on viral nucleic acids and viral specific primers or probes. PCR is the most commonly used detection technique for begomoviruses and primers were primarily designed on coat protein and replicase genes (41). Among the viral proteins, coat protein has been shown to be important for the infection and propagation of the virus. This gene was reported to be conserved among begomoviruses and many primers designed in this region were utilized for PCR based detection of begomovirus (42). The major advantages of molecular techniques are specificity, sensitivity, faster detection and multiplexing $(43,44)$. Though most molecular techniques are robust, there are drawbacks like non-specific amplification, inhibition of polymerases activity due to the presence of phenolics, polysaccharides in the nucleic acids (45).

Simple and convenient technologies for the identification of chemical and biological species are of great significance in environmental monitoring, public health and disease diagnosis $(46,47)$. Here we report the development of functionalized gold nanoparticles (AuNPs) based visual detection method that relies on hybridization principle. Gold nanoparticles (AuNPs) have been routinely used for the development of visual detection methods for many pathogens due to their unique colour properties and tunable localized surface plasmon resonance (SPR) (48). Surface plasmon resonance has been shown to be dependent on NP (nanoparticle) composition, size and shape $(49,50)$.

Detection methods based on functionalized nanoparticles were found to be highly sensitive with faster turnover than the other methods like PCR, ELISA. Early detection of plant pathogens is critical for the management of infections in plants as it would result in better segregation of healthy plants and infected plants at the earliest, thus preventing the spread of disease in a farm or field (51). Recently, a visual DNA method using integrated Recombinase Polymerase amplification (RPA) and a AuNP probe has been reported for detection of tomato yellow leaf curl virus and was found to be highly sensitive and stable (52). In our lab, we had developed a method for detection of Banana Bunchy Top Virus (BBTV) using functionalized AuNPs (53). In this work, we demonstrated the applicability of functionalized AuNPs in the 
detection of begomoviruses in plants and an Indian patent has been filed (Application No: 201941007582).

\section{Materials And Methods Plant material}

The leaf samples of Capsicum annuum $(\mathrm{n}=99)$, Solanum lycopersicum $(\mathrm{n}=79)$ (Family: Solanaceae) and Phaseolus vulgaris (Family: Fabaceae) $(n=4)$ were collected from open fields in various regions of TamilNadu, India. The leaf sample from the following plants, Plectranthus amboinicus (Family: Lamiaceae) Catharanthus roseus (Family: Apocynaceae) were collected from Chennai, Tamil Nadu and Indigofera aspalathoides (Family: Fabaceae) was collected from Madurai, Tamil Nadu. The above three plants served as internal controls (plant DNA) to determine the specificity of the probes employed. For positive control, begomoviral infected leaf samples of plants belonging to the Fabaceae family (Vigna mungo $[n=1]$ and Vigna radiata $[n=1])$ were obtained from TNAU (Dr. K.K. Kumar, Associate Professor, Department of Plant Biotechnology, Tamil Nadu Agricultural University (TNAU), Coimbatore).

\section{Isolation of total DNA from plants}

The total DNA was isolated from the plants by Dellaporta DNA isolation method (54) with few modifications. Briefly, $2 \mathrm{~g}$ of leaf tissue was ground to a fine powder using liquid nitrogen, transferred to a sterile falcon tube $(50 \mathrm{ml})$ followed by the addition of $5 \mathrm{ml}$ of extraction buffer [100 mM Tris $(\mathrm{pH} 8.0)$, $50 \mathrm{mM}$ EDTA, $500 \mathrm{mM} \mathrm{NaCl}$, and $10 \mathrm{mM} \beta$-mercaptoethanol]. The mixture was vortexed and $660 \mu \mathrm{l}$ of $10 \%$ SDS was added, mixed thoroughly and incubated at $65^{\circ} \mathrm{C}$ for $10 \mathrm{~min}$. Then, $1.6 \mathrm{ml}$ of $5 \mathrm{M}$ potassium acetate was added and centrifuged at $8000 \mathrm{rpm}$ for $15 \mathrm{~min}$ at $4{ }^{\circ} \mathrm{C}$. The supernatant was transferred to a fresh tube and an equal volume of ice-cold chloroform was added and centrifuged at $8000 \mathrm{rpm}$ for 15 min at $4{ }^{\circ} \mathrm{C}$. The supernatant was transferred to a fresh tube and an equal volume of ice-cold isopropanol was added, mixed and allowed to rest for 15-20 min at room temperature. The total DNA was precipitated by centrifugation at $8000 \mathrm{rpm}$ for $15 \mathrm{~min}$ at $4{ }^{\circ} \mathrm{C}$. The pellet was washed with $70 \%$ icecold ethanol at $8000 \mathrm{rpm}$ for $10 \mathrm{~min}$. The pellet was air-dried and resuspended in 30-50 $\mu \mathrm{l}$ of sterile distilled water. The quality and quantity of the total DNA were analyzed using Nanodrop.

\section{Screening of begomovirus in plants by PCR}

Total DNA isolated from plants (chilli - 99 No's, tomato - 79 No's, common bean - 4 No's) were screened for begomovirus using Taq DNA Polymerase 2X Master Mix RED with $1.5 \mathrm{mM} \mathrm{MgCl}_{2}$ (Synergy Scientific) and gemini virus specific primers - Deng primers (Deng A 5' TAATATTACCKGWKGVCCSC 3' and Deng B 5' TGGACYTTRCAWGGBCCTTCACA 3') (55) for 30 cycles and results were documented.

\section{Cloning and Sequencing of partial coat protein of begomovirus}


The PCR product (Deng primers) of one of the positive samples was cloned using InsTAclone kit and $E$. coli DH5 $\boldsymbol{\alpha}$ was transformed as per instructor's manual and one of the clones was sequenced (56).

\section{Designing of probe for begomovirus detection}

The probe for coat protein gene of chilli was designed based on the sequence obtained in this study and the probes for replicase gene of chilli and tomato were designed based on the GenBank sequences (FM877858.1 and AY260505.1) respectively using online tool PRIMER QUEST. Both thiolated and nonthiolated probes were obtained from Sigma Aldrich, Chennai and suspended in MilliQ water at $100 \mu \mathrm{M}$ concentration.

\section{Functionalization of thiolated probes}

The thiolated probes $(10 \mathrm{nM})$ were functionalized by treating with freshly prepared dithiothreitol (DTT) and purified as described in Kumar et al., 2017. Briefly, $1 \mathrm{ml}$ of $10 \mathrm{nM}$ thiolated probe was treated with $100 \mu \mathrm{l}$ of DTT and incubated for $30 \mathrm{~min}$ at RT and purified using NAP2 5 column as per manufacturer's instructions (GE Lifesciences) and used for conjugation of gold nanoparticles (AuNPs).

\section{AuNP synthesis and conjugation with probes}

Gold nanoparticles (AuNPs) were synthesized by citrate reduction method and conjugated with thiolated probes as described in earlier reports (53) and stored at $4{ }^{\circ} \mathrm{C}$. One gram of gold chloride $\left[\mathrm{HAuCl}_{4} \otimes \mathrm{H}_{2} \mathrm{O}\right.$ (SRL, India, Cat. No. 12023)] was suspended in $1 \mathrm{ml}$ of MilliQ water and used for the synthesis of gold nanoparticles. Briefly, $50 \mathrm{ml}$ of Milli Q water and $5 \mu \mathrm{l}$ of gold chloride were mixed in a spoutless beaker and a round bottomed flask filled with water was kept on the top to prevent evaporation. The mixture was brought to boiling temperature and $750 \mu$ of $1 \%$ trisodium citrate dihydrate (Merck) was added and boiled further for $10 \mathrm{~min}$. The mixture turned blue, then gradually to cherry red by the end of $10 \mathrm{~min}$. The AuNPs thus synthesised were allowed to cool at RT and were stored in $50 \mathrm{ml}$ falcon tube at $4{ }^{\circ} \mathrm{C}$ until further use.

The freshly synthesized AuNPs were conjugated with non-thiolated probes by $\mathrm{pH}$ dependent citrate conjugation method (57) with slight modifications. To $1 \mathrm{ml}$ of AuNPs, $5 \mu$ of non-thiolated probe ( 100 $\mu \mathrm{M}$ ) was added, vortexed gently and $20 \mu \mathrm{l}$ of $500 \mathrm{mM}$ sodium citrate- $\mathrm{HCl}(\mathrm{pH} 3)$ was added and incubated at room temperature for $3 \mathrm{~min}$. Then, $60 \mu \mathrm{l}$ of $10 \mathrm{mM}$ HEPES (pH 7.6) was added, mixed by inversion and incubated at room temperature for $5 \mathrm{~min}$. The mixture was then centrifuged at 12,000 rpm for 5 to $10 \mathrm{~min}$. The pellet was suspended in $50 \mu \mathrm{l}$ of resuspension buffer [ $10 \mathrm{mM}$ phosphate buffered saline (PBS) $\mathrm{pH} 7.4 ; 0.1 \%$ SDS], covered in aluminium foil and stored at RT until use.

The freshly synthesized AuNPs were conjugated with activated thiolated probes by salt-ageing method (58) with slight modifications. Briefly, to $15 \mathrm{ml}$ of AuNPs, $300 \mu \mathrm{l}$ of activated thiolated probe was added and incubated for $30 \mathrm{~min}$ in an orbital shaker at RT overnight for $90 \mathrm{rpm}$. Then, $297 \mu \mathrm{l}$ of $100 \mathrm{mM}$ phosphate buffer $(\mathrm{pH} 7)$ was added, followed by addition of $165 \mu$ of $10 \%$ SDS. The mixture was further incubated for $30 \mathrm{~min}$ in an orbital shaker $90 \mathrm{rpm}$ at RT. Finally, six doses of $81 \mu \mathrm{l}$ of $2 \mathrm{M} \mathrm{NaCl}$ in $100 \mathrm{mM}$ PBS ( $\mathrm{pH} 7$ ) was added to the mixture over a period of 2 days in an orbital shaker $90 \mathrm{rpm}$ at RT. The 
functionalized AuNPs were purified in aliquots of $1 \mathrm{ml}$ in $1.5 \mathrm{ml}$ centrifuge tubes by centrifugation at $12000 \mathrm{rpm}$ for $10 \mathrm{~min}$ and washed with $500 \mu \mathrm{l}$ of resuspension buffer [ $100 \mathrm{mM}$ phosphate buffered saline (PBS) pH 7.4; 0.1\% SDS]. Finally, the functionalized AuNPs were suspended in $50 \mu \mathrm{l}$ of resuspension buffer, covered in aluminium foil and stored at RT until use.

\section{Characterization of AuNPs}

The synthesized unmodified AuNPs were characterized by Surface Electron Microscopy (SEM), Transmission Electron Microscopy (TEM) and Energy Dispersive X-ray Spectroscopy (EDX) at Sophisticated Instrument Facility (SIF), Vellore Institute of Technology (VIT). The size and zeta potential of the functionalized AuNPs were analyzed using Particle Size Analyzer (Horiba Scientific SZ-100) at TRPVB, Madhavaram, Chennai, India.

\section{AuNP assay for begomovirus detection}

The total DNA from chilli plants $(100 \pm 10 \mathrm{ng} / \mu \mathrm{l})$ were diluted $(1: 5)$, tomato plants $(100 \pm 10 \mathrm{ng} / \mu \mathrm{l})$ were diluted (1:10) with MilliQ water and utilized for AuNP assay. The assay was performed in a PCR machine (G Storm) and had the following steps - diluted total DNA (5 $\mu$ l) was denatured at $95^{\circ} \mathrm{C}$ for $5 \mathrm{~min}$ followed by addition of $5 \mu$ of functionalized AuNP and annealing was done at $65^{\circ} \mathrm{C}$ for $10 \mathrm{~min}$. Finally, $5 \mu \mathrm{l}$ of $2 \mathrm{M} \mathrm{NaCl}$ prepared in MilliQ water was added and the results were recorded within $20 \mathrm{~min}$. The clone (pTZCCPp3) that carried the partial coat protein gene of begomovirus was used as positive control for probe clccpi1 thiol, whereas MilliQ water served as negative controls.

\section{Specificity and Sensitivity of AuNP assay}

To confirm the specificity and sensitivity of the assay, the plasmid (pTZCCPp3 carrying partial coat protein DNA) served as positive control and MilliQ as a negative control. The total DNA from other plants belonging to the other genera, which are not susceptible to begomovirus, Indigofera aspalathoides, Plectranthus amboinicus and Catharanthus roseus were tested against the functionalized AuNPs. The clone (pTZCCPp3) was diluted with MilliQ water, the different concentrations $(100 \mathrm{ng} / \mu \mathrm{l}, 10 \mathrm{ng} / \mu \mathrm{l}, 10 \mathrm{pg} /$ $\mu \mathrm{l}$ and $1 \mathrm{pg} / \mathrm{\mu l}$ ) were analyzed by PCR using M13 primers. Different concentrations of the clone (pTZCCPp3) $(1 \mathrm{ng} / \mu \mathrm{l}, 1 \mathrm{pg} / \mu \mathrm{l}, 500 \mathrm{fg} / \mu \mathrm{l}, 1 \mathrm{fg} / \mu \mathrm{l}, 500 \mathrm{ag} / \mu \mathrm{l}$ and $1 \mathrm{ag} / \mu \mathrm{l})$ were tested using AuNP assay.

\section{Results}

\section{DNA isolation from chilli and tomato leaves}

A total of 99 chilli samples and 79 tomato samples were used in this study and total DNA was isolated using Dellaporta method. The total DNA obtained from chilli and tomato plants were analyzed by agarose gel electrophoresis and Nanodrop. The DNA obtained from tomato samples had brownish tinge and were viscous, whereas DNA from chilli samples had aqueous consistency and transparent. Total DNA from other plants (Phaseolus vulgaris, Vigna radiata, Vigna mungo, Indigofera aspalathoides, Plectranthus amboinicus and Catharanthus roseus) used in this study also had good quality. 


\section{Screening of chilli and tomato plants by PCR for begomovirus infection}

The chilli and tomato samples (99 No's and 79 No's) were then screened for begomovirus infection by PCR using Deng primers. PCR was also done for housekeeping gene 18S rRNA for both chilli and tomato samples and amplification was observed for chilli samples but not for tomato samples (data not shown) (56). Out of 99 chilli DNA samples, 49 samples were found to be positive for PCR with Deng primers (amplicon of $\cong 530 \mathrm{bp}$ ) (Fig. 1a). PCR analysis of a few tomato samples using Deng primers were negative.

\section{Cloning and Sequencing of coat protein region of begomovirus}

The Begomoviral DNA was amplified from chilli samples using Deng A and Deng B primers and the PCR positive chilli plants (49 samples) had an amplicon of $\sim 530 \mathrm{bp}$. One of the PCR products was cloned and sequenced using M13 sequencing primers. The sequence obtained from the clone, pTZCCPp3 was then analyzed by blastn and was found to be coat protein (partial) of chilli leaf curl virus (56). The sequence was then submitted to Genbank with the accession number MH500267 (Fig. 2).

\section{Synthesis and Conjugation of AuNPs with clccpi1, chrppro1 and torppro1 probes}

AuNPs synthesized by citrate reduction method were cherry red in colour and were further characterized by TEM and EDX (Fig. 3a and 3b). The size of the unmodified AuNPs was found to be $\cong 20 \mathrm{~nm}$ and the elemental composition analysis showed the presence of gold. Gold nanoparticles were then conjugated with thiolated probes (clccpi1 thiol, chrppro1 thiol and torppro1 thiol) by salt-ageing method and were found to retain the red colour. The average size of functionalized gold nanoparticles was found to be $\cong$ $32.8 \mathrm{~nm}$ and the zeta potential of functionalized gold nanoparticles was found to be $-49.9 \mathrm{mV}$ (Fig. $4 \mathrm{a}$ and $4 b)$.

\section{Screening of plants for begomoviral infection by AuNP assay}

Surface plasmon resonance property of functionalized gold nanoparticles was utilized for the development of AuNP assay. The reaction mixture consisted of template DNA (total DNA) from plants, functionalized AuNPs and salt. When the samples retained the red colour, it indicated the presence of begomovirus whereas change of colour from red to purple indicated the absence of begomovirus.

\section{Chilli plants}


The AuNP assay was performed in duplicates for all the 99 chilli samples. AuNP assay was carried out with three sets of probes (clccpi1 thiol, chrppro1 thiol and chrppro1). Data of the AuNP assay of chilli samples with clccpi1 thiol probe and chrppro1 thiol probe was provided (Fig. 5a and 5b). Out of 99 samples, 77 samples were found to be positive with AuNP assay (clccpi1 thiol and chrppro1 thiol probes), whereas 70 samples were positive with chrppro1 probe (non-thiolated). PCR (Deng primers) analysis detected only 49 samples as positives (Fig. 6).

\section{Tomato plants}

The AuNP assay was performed in duplicates for 79 tomato samples. The AuNP assay was carried out with three sets of probes (torppro1 thiol, torppro1 and clccpi1 thiol). Data of the AuNP assay of tomato samples with clccpi1 thiol probe and torppro1 thiol probes was provided (Fig. 6a and 6b). Out of 79 samples, 43 samples were found to be positive with AuNP assay (clccpi1 thiol probe and torppro1 thiol probes) and 39 samples were positive with torppro1 probe (Fig. 6c).

\section{Sensitivity and specificity of the AuNP assay}

To test the sensitivity of the AuNP assay with clccpi1 thiol probe, plasmid (pTZCCPp3) carrying partial coat protein region of begomovirus was diluted to different concentrations $(1 \mathrm{ng} / \mu \mathrm{l}$ to $1 \mathrm{ag} / \mu \mathrm{l})$ using Milli $\mathrm{Q}$ water and assayed. Similar concentrations were also screened by PCR using Deng primers. The AuNP assay was able to detect plasmid up to $500 \mathrm{ag} / \mu \mathrm{l}$, whereas PCR detected plasmid up to $10 \mathrm{ng} / \mu \mathrm{l}$ (Fig. $7 \mathrm{a}$ and 7b). The specificity of the AuNP assay with clccpi1 thiol probe was tested with total DNA from three plants belonging to different genera (Indigofera aspalathoides, Plectranthus amboinicus and Catharanthus roseus) that are not affected by begomovirus were chosen and AuNP probe assay was found to be negative (Fig. 8a).

\section{Versatility of the AuNP assay}

Symptomatic and Asymptomatic samples (4 Nos.) of common bean (Phaseolus vulgaris) were collected from Chennai, TamilNadu. Begomovirus infected plants (Vigna mungo and Vigna radiata) were obtained from Tamil Nadu Agricultural University, India (Dr. K K Kumar, Department of Plant Biotechnology) and served as positive control. The AuNP assay with clccpi1 thiol probe was performed with total DNA from plants belonging to Fabaceae family [Common bean (Phaseolus vulgaris [ $n=4]$ ), mung bean (Vigna radiata, $[\mathrm{n}=1]$ ) and black gram (Vigna mungo, $[\mathrm{n}=1])$ ]. Of the 4 common bean samples, 2 were found to be positive by PCR and AuNP assay. The PCR analysis with Deng primers showed an amplicon of $530 \mathrm{bp}$ and $~ 600 \mathrm{bp}$ for B3 and B4 bean samples respectively (Fig. 8b \& 8c). The clccpi1 thiol probe (coat protein gene) was able to detect Mung bean yellow mosaic virus in both Vigna varieties (Fig. 8d). The probes based on replicase gene of chilli and tomato (chrppro1 thiol and torppro1 thiol) were able to detect only begomovirus of chilli and tomato respectively (data not shown).

\section{Discussion}




\section{Screening of plants for begomovirus by PCR}

The total DNA was isolated from all the plants (symptomatic and asymptomatic) under study using Dellaporta method (54). The total DNA isolated from the plants had 260/280 ratio around 1.8-2 when analyzed in nanodrop and intact bands were observed on agarose gel. These confirmed that most of the genomic DNA was intact and could be used for PCR except for tomato samples which were pale brown to brown due to phenolics. PCR analysis of the plants (chilli and common bean) for 18S rRNA and begomovirus DNA (Deng primers) showed amplification whereas tomato samples were negative for PCR analysis (both primers) (Figs. 1 \& 8c). The absence of bands in PCR analyses of tomato plants could be due to the excessive phenolics and polysaccharides observed in tomato DNA samples, which were known to inhibit polymerase activity (59).

Previous reports on screening of begomovirus in plants have shown utilization of different primers with varied success (60-63). Deng primers (Deng A and Deng B) were designed on the coat protein (CP) of begomoviruses as the $\mathrm{CP}$ gene was highly conserved across the genus (64). The $\mathrm{CP}$ gene has a significant role in encapsidation of the viral DNA and is implicated in viral movement within the plant as well as in whitefly transmission $(9,65-67)$. Hence for PCR detection, the most common target is the begomoviral coat protein $(\mathrm{CP})$ gene $(68,69)$ and hence Deng primers were utilized in this study. Among the chilli plants (99 No's) screened for begomoviral infection by PCR, 49 samples were found to be positive. The PCR with 18S rRNA for all the chilli plants were found to be positive, thus confirming the absence of bands in PCR with Deng primers was due to absence of begomovirus and not due to the presence of any inhibitors in those samples. The coat protein region of begomovirus from a PCR positive chilli plant was amplified using Deng primer, cloned and sequenced (56). The sequence analysis revealed the presence of partial coat protein sequence and was deposited in GenBank with accession number (MH500267) (Fig. 2).

\section{Probe design}

Five different probes ( 3 thiolated and 2 non-thiolated) based on coat protein ( 1 probe) and replicase protein (4 No's) of begomovirus were designed and used in this work (Table 1). The replicase gene probes (thiolated and non-thiolated) (Table 1) for chilli and tomato plants were designed based on GenBank sequences, FM877858.1 \& AY260505.1 respectively. The coat protein probe (thiolated and non-thiolated) for chilli plant was designed based on the sequence obtained in this study (MH500267.1). Different probes (coat protein and replicase gene) were designed to determine if there are any differences in the detection limit or specificity among the probes. 
Table 1

Probes used in this study

\begin{tabular}{|ll|}
\hline Probes & Sequence $\left(\mathbf{5}^{\prime} \mathbf{-} \mathbf{3}^{\prime}\right.$ ) \\
\hline clccpi1thiol & [ThiC6]TTCCGATTCATGGGCCTGTT \\
\hline chrppro1 & TTGACATCGGAGCTGGACTTTGCT \\
\hline chrppro1thiol & [ThiC6]TTGACATCGGAGCTGGACTTTGCT \\
\hline torppro1 & ACTGCATTCTTGATTGCCCACTGC \\
\hline torppro1thiol & [ThiC6]ACTGCATTCTTGATTGCCCACTGC \\
\hline
\end{tabular}

\section{AuNP synthesis and conjugation with probes}

Gold nanoparticles (AuNPs) synthesized were cherry red in colour, average size of the unmodified AuNPs was found to be $\sim 20 \mathrm{~nm}$ and elemental analysis confirmed the presence of $\mathrm{Au}$ in the colloidal suspension (Fig. 3a). The AuNPs were then conjugated with probes either by salt-ageing method (thiolated probes) or $\mathrm{pH}$ dependent citrate method (non-thiolated probes). All the functionalized AuNPs remained red in colour thus confirming the stability of AuNPs upon functionalization with different probes. Particle size analysis and Zeta potential measurement of the functionalized AuNPs with chrppro1 thiol probe were $32.8 \mathrm{~nm}$ and $-49.9 \mathrm{mV}$ respectively, which confirmed the formation of negative charges on the surface of synthesized AuNPs. Negative charge on AuNPs is due to citrate which acts as both a reducing and a stabilizing agent that results in repulsion between AuNPs thus prevents the aggregation of AuNPs (70). A narrow peak pattern revealed that functionalized gold nanoparticles possessed good stability (Fig. 4a \& 4b).

\section{AuNP probe assay}

AuNP probe assay is based on hybridization of a specific probe (coat protein or replicase gene of begomovirus) and its target DNA (begomoviral DNA). Upon hybridization, the mixture was treated with salt to detect the presence of begomovirus. Retention of red colour indicated the presence of begomovirus as the AuNPs were protected due to hybridization of probe and viral DNA (coat protein or replicase gene). In the absence of begomovirus, the probes on the AuNPs are free and upon addition of salt, the negative charges (electron cloud) on the AuNPs gets neutralized thereby resulting in change of colour from red to purple (71). AuNP assay with thiolated probes (clccpi1 thiol and chrppro1 thiol) detected 77 chilli plants as infected with begomovirus and 70 samples as positive with non-thiolated probes (clccpi1 and chrppro1). The difference in the number of positive samples between the probes (thiolated and non-thiolated) showed that thiolated probes were better than non-thiolated probes (Fig. 5). This could be due to ordered and spacious arrangement of thiolated probes onto AuNPs than nonthiolated probes, as low concentrations of thiolated probes $(\sim 10 \mathrm{nM})$ were used in salt-ageing method as compared with $\mathrm{pH}$ based citrate conjugation method (non-thiolated probe - 100 $\mu \mathrm{M}$ ). AuNP assay was found to be better than PCR in detecting begomoviral infection in chilli plants as AuNP assay detected 77 samples as infected whereas PCR detected only 49 samples (Fig. 5c). 
AuNP assay of 79 tomato samples showed that 43 samples were infected with begomovirus. Three probes (clccpi1 thiol, torppro1 thiol and torppro1) were used in the assay and the thiolated probes detected equal number of samples (43 No's) whereas non-thiolated probe detected 39 samples as infected (Fig. 6). This showed that the AuNP assay was not affected by the presence of phenolics or polysaccharides that hamper methods like PCR due to inhibition of polymerase activity (59). Recently, DNA templated 3D self-assembly of AuNPs clusters using bi-functional oligonucleotide probe was developed for tomato leaf curl virus (70). Another method using LAMP PCR was developed that detected Indonesian begomovirus isolates (ToLCNDV, PepYLCIV, and TYLCKaV) simultaneously and rapidly under field conditions for routine survey (72). But in this method, there is a need to employ pre-ordered mix and a small instrument and it takes more than 30 minutes to complete the assay and only few samples could be assayed.

In our lab, we have developed an AuNP probe-based method for the detection of BBTV in banana plants and was found to be better than PCR (53). Overall, the detection efficiency of AuNP assay (77.7\%) was found to be better than PCR screening (49.4\%) in case of chilli plants. Thiolated probes (coat protein and replicase genes) were found to perform better than non-thiolated probes in chilli and tomato plants. Among the probes, clccpi1 thiol (based on coat protein region of chilli leaf curl virus) was found to be unique as it was able to detect begomovirus of both chilli and tomato plants efficiently (Figs. $5 \& 6$ ). Since the clccpi 1 thiol probe was designed on the conserved region of coat protein of chilli leaf curl virus it was able to detect begomoviruses infecting chilli and tomato plants belonging to the Solanaceae family. The probes based on replicase genes of chilli and tomato (chrppro1 thiol and torppro1 thiol) were able to detect only begomovirus of chilli and tomato samples respectively thus confirming their specificity.

\section{Sensitivity and specificity of AuNP assay with clccpi1 thiol}

The clone (pTZCCPp3) that carried the partial coat protein gene of begomovirus was diluted in MilliQ water and used to determine the detection limit of both AuNP assay and PCR analysis (Deng primers). AuNP assay detected plasmid upto $500 \mathrm{ag} / \mu \mathrm{l}$ whereas PCR detected plasmid only upto $10 \mathrm{ng} / \mu \mathrm{l}$ (Fig. 7). This confirmed that AuNP assay had better sensitivity than PCR and the detection limit was similar to our earlier work with BBTV (53). The specificity assay was performed with total DNA from different healthy plants and was found to be negative thereby confirming that the probe (clccpi1 thiol) was specific to begomoviral DNA and not to plant DNA (Fig. 8a).

\section{Versatility of AuNP assay}

To further validate the versatility of the clccpi1 thiol probe, plants belonging to Fabaceae family that are prone for begomoviral infection were also screened. Three samples viz., common bean (Phaseolus vulgaris $[n=4]$ ), mung bean (Vigna radiata, $[n=1]$ ) and black gram (Vigna mungo, $[n=1]$ ) were screened. The viral infected leaves of mung bean and black gram were obtained from TNAU and served as positive controls. The AuNP assay was able to detect begomoviral infection in those samples (Fig. 8b - d) and PCR analysis (Deng primers) also correlated thus confirming the versatility. These results confirmed that 
clccpi1 thiol probe was able to detect begomoviruses infecting plants belonging to different genera (Solanaceae and Fabaceae) in a robust manner. The begomoviruses that were detected by AuNP assay (with clccpi1 thiol) in this study are Chilli leaf curl virus (CLCV), Tomato leaf curl virus (ToLCV), Mung bean Yellow Mosaic Virus (MYMV) (Vigna radiata and Vigna mungo) and Bean Golden Yellow Mosaic Virus (BGYMV) (Phaseolus vulgaris).

Whitefly transmitted begomoviruses causes huge losses to wide varieties of crops in India and worldwide. Pepper-infecting begomoviruses occur in India, Indonesia, Africa, Mexico, Central America, and the southern United States. Begomoviruses that infect tomato are more widely distributed and seriously impact production in tropical and subtropical regions worldwide. Monopartite begomoviruses infect peppers in Asia (e.g., Chilli leaf curl virus and Pepper leaf curl Bangladesh virus) and Africa (e.g., Pepper yellow vein Mali virus), whereas the bipartite Pepper yellow leaf curl Indonesia virus occurs in Indonesia $(45,73-78)$. The importance and diversity of begomoviruses infecting Capsicum species have increased over the past $5-10$ years (73). On the Indian subcontinent in particular, leaf curl disease caused by a complex of begomoviruses and beta-satellites is considered a major constraint on pepper production (79). Efficient viral resistant crops are still in various development stages and the simplest and effective means of controlling and managing these pathogens is the earliest possible detection and removal of infected plants from the fields. In this context, the present study gains importance as we demonstrate a versatile method that is simple to perform, does not require amplification step and is highly sensitive than other methods like PCR, ELISA that are hampered by the presence of inhibitors like phenolics, polysaccharides.

\section{Declarations}

\section{Ethics approval and consent to participate}

Institutional ethical clearance was obtained for this study, IEC-NI/14/DEC/44/75, dated December 22, 2014. Consent to participate is not applicable.

\section{Consent for publication}

The authors declare their consent for publication.

\section{Availability of data and materials}

The data and the materials used in the current study are available with the corresponding author and can be produced on need.

\section{Competing interests}

The authors declare no competing interest.

\section{Funding}


The present work was not supported by any funding organizations.

\section{Authors' contributions}

LR performed bench works, worked on the study design and flow, performed analysis and wrote the manuscript. AV performed conception and designed the study, analysed the data, supported for patent filing and analysed the manuscript. All the authors read and approved the final manuscript.

\section{Acknowledgements}

The authors are grateful for SRIHER management for the Founder Chancellor Sri N.P.V. Ramasamy Udayar Research Fellowship (2013-16).

\section{References}

1. Matthews REF. Host Plant Responses to Virus Infection. In: Comprehensive Virology. 1980. p. 297359.

2. Gibbs A, Ohshima K. Potyviruses and the digital revolution. Annu Rev Phytopathol. 2010;48:205-23.

3. Scholthof K-BG, Adkins S, Czosnek H, Palukaitis P, Jacquot E, Hohn T, et al. Top 10 plant viruses in molecular plant pathology. Mol Plant Pathol. 2011 Dec;12(9):938-54.

4. Goodman RM. Geminiviruses. J Gen Virol. 1981 May 1;54(1):9-21.

5. Varsani A, Navas-Castillo J, Moriones E, Hernández-Zepeda C, Idris A, Brown JK, et al. Establishment of three new genera in the family Geminiviridae: Becurtovirus, Eragrovirus and Turncurtovirus. Arch Virol. 2014 Aug;159(8):2193-203.

6. Varsani A, Roumagnac P, Fuchs M, Navas-Castillo J, Moriones E, Idris A, et al. Capulavirus and Grablovirus: two new genera in the family Geminiviridae. Arch Virol. 2017 Jun;162(6):1819-31.

7. Zerbini FM, Briddon RW, Idris A, Martin DP, Moriones E, Navas-Castillo J, et al. ICTV Virus Taxonomy Profile: Geminiviridae. J Gen Virol. 2017 Feb;98(2):131-3.

8. Moffat AS. Geminiviruses emerge as serious crop threat. Science. 1999;286(5446):1835-1835.

9. Hanley-Bowdoin L, Settlage SB, Orozco BM, Nagar S, Robertson D. Geminiviruses: models for plant DNA replication, transcription, and cell cycle regulation. Crit Rev Biochem Mol Biol. 2000;35(2):10540.

10. Gutierrez C. Geminiviruses and the plant cell cycle. Plant Mol Biol. 2000 Aug;43(5-6):763-72.

11. Hawkes JG, Lester RN, Skelding AD. The Biology and taxonomy of the Solanaceae. Academic Press; 1979. $738 \mathrm{p}$.

12. Olmstead RG, Bohs L, Migid HA, Santiago-Valentin E, Garcia VF, Collier SM. A molecular phylogeny of the Solanaceae. Taxon. 2008;57(4):1159-81.

13. Zhou XP, Xie Y, Zhang ZK. Molecular characterization of a distinct begomovirus infecting tobacco in Yunnan, China. Arch Virol. 2001 Aug;146(8):1599-606. 
14. Xie Y. Tobacco curly shoot virus isolated in Yunnan is a distinct spe-cies of Begomovirus. Chin Sci Bull. 2002;47(3):197.

15. Mansoor S, Briddon RW, Bull SE, Bedford ID, Bashir A, Hussain M, et al. Cotton leaf curl disease is associated with multiple monopartite begomoviruses supported by single DNA $\beta$. Arch Virol. 2003 Oct 1;148(10):1969-86.

16. Varma A, Malathi VG. Emerging geminivirus problems: A serious threat to crop production. Ann Appl Biol. 2003 Apr;142(2):145-64.

17. Rojas MR, Macedo MA, Maliano MR, Soto-Aguilar M, Souza JO, Briddon RW, et al. World Management of Geminiviruses. Annu Rev Phytopathol. 2018 Aug 25;56:637-77.

18. Mishra MD, Raychaudhuri SP, Ashrafi J. Virus causing leaf curl of Chilli (Capsicum annuum L.). Indian journal of [Internet]. 1963; Available from: https://www.cabdirect.org/cabdirect/abstract/19651102318

19. Khan ZA, Khan JA. Characterization of a new begomovirus and betasatellite associated with chilli leaf curl disease in India. Arch Virol. 2017 Feb;162(2):561-5.

20. Juárez M, Tovar R, Fiallo-Olivé E, Aranda MA, Gosálvez B, Castillo P, et al. First Detection of Tomato leaf curl New Delhi virus Infecting Zucchini in Spain. Plant Dis. 2014 Jun 1;98(6):857-857.

21. Macedo MA, Barreto SS, Costa TM, Rocha GA, Dianese EC, Gilbertson RL, et al. First Report of Tomato severe rugose virus, a Tomato-Infecting Begomovirus, in Soybean Plants in Brazil. Plant Dis. 2017 Nov 1;101(11):1959-1959.

22. López MM, Llop P, Olmos A, Marco-Noales E, Cambra M, Bertolini E. Are molecular tools solving the challenges posed by detection of plant pathogenic bacteria and viruses? Curr Issues Mol Biol. 2009;11(1):13-46.

23. Clark MF, Adams AN. Characteristics of the microplate method of enzyme-linked immunosorbent assay for the detection of plant viruses. J Gen Virol. 1977 Mar;34(3):475-83.

24. McLaughlin MR, Barnett OW, Burrows PM, Baum RH. Improved ELISA conditions for detection of plant viruses. J Virol Methods. 1981 Jul 1;3(1):13-25.

25. Hewings AD, D'Arcy CJ. Maximizing the detection capability of a beet western yellows virus ELISA system. J Virol Methods. 1984 Oct;9(2):131-42.

26. Makkouk KM, Hsu HT, Kumari SG. Detection of Three Plant Viruses by Dot-Blot and Tissue-Blot Immunoassays Using Chemiluminescent and Chromogenic Substrates. J Phytopathol. 1993 Oct;139(2):97-102.

27. Derrick KS. Quantitative assay for plant viruses using serologically specific electron microscopy. Virology. 1973 Dec;56(2):652-3.

28. Milne RG. Immunoelectron Microscopy for Virus Identification. In: Mendgen K, Lesemann D-E, editors. Electron Microscopy of Plant Pathogens. Berlin, Heidelberg: Springer Berlin Heidelberg; 1991. p. 87102. 
29. Van Regenmortel MHV. Serology and Immunochemistry of Plant Viruses. Immunol Commun. 1982 Jan 1;11(6):509-25.

30. Mullis K, Faloona F, Scharf S, Saiki R, Horn G, Erlich H. Specific Enzymatic Amplification of DNA In Vitro: The Polymerase Chain Reaction. Cold Spring Harb Symp Quant Biol. 1986 Jan 1;51:263-73.

31. Henson JM, French R. The polymerase chain reaction and plant disease diagnosis. Annu Rev Phytopathol. 1993;31:81-109.

32. Levy L, Hadidi A, Kolber M, Tokes G, Nemeth M. 3â NON-CODING REGION RT-PCR DETECTION AND MOLECULAR HYBRIDIZATION OF PLUM POX VIRUS IN ANTHERS OF INFECTED STONE FRUIT. Acta Hortic. 1995 Jul;(386):331-9.

33. Candresse T, Lanneau M, Revers F, Kofalvi S, Macquaire G. PCR-BASED TECHNIQUES FOR THE DETECTION OF PLANT VIRUSES AND VIROIDS. Acta Hortic. 2000 Sep;(530):61-7.

34. Maule AJ, Hull R, Donson J. The application of spot hybridization to the detection of DNA and RNA viruses in plant tissues. J Virol Methods. 1983 Apr;6(4):215-24.

35. Garger SJ, Turpen T, Carrington JC, Morris TJ, Jordan RL, Dodds JA, et al. Rapid detection of plant RNA viruses by dot blot hybridization. Plant Mol Biol Rep. 1983 Mar 1;1(1):21-5.

36. Owens RA, Diener TO. 6 - Spot Hybridization for Detection of Viroids and Viruses. In: Maramorosch K, Koprowski H, editors. Methods in Virology. Elsevier; 1984. p. 173-87.

37. Rosner A, Lee RF, Bar-Joseph M. Differential hybridization with cloned cDNA sequences for detecting a specific isolate of citrus tristeza virus. Phytopathology [Internet]. 1986; Available from: http://agris.fao.org/agris-search/search.do?recordID=US8707556

38. Baulcombe DC. Detection of Strains of Potato Virus X and of a Broad Spectrum of Potato Virus $Y$ Isolates by Nucleic Acid Spot Hybridization (NASH). Plant Dis. 1988;72(4):307.

39. Palukaitis P. 9 - Detection and Characterization of Subgenomic RNA in Plant Viruses. In: Maramorosch K, Koprowski H, editors. Methods in Virology. Elsevier; 1984. p. 259-317.

40. Kumar S, Jaidi M, Raj SK. Molecular characterization of a Begomovirus and Betasatellite infecting wild sunflower (Helianthus spp.) in India. Virology Research Journal. 2016;1(1):1-9.

41. Saiki RK, Gelfand DH, Stoffel S, Scharf SJ, Higuchi R, Horn GT, et al. Primer-directed enzymatic amplification of DNA with a thermostable DNA polymerase. Science. 1988 Jan 29;239(4839):48791.

42. Sohrab SS, Mandal B, Pant RP, Varma A. First Report of Association of Tomato leaf curl virus-New Delhi with Yellow Mosaic Disease of Luffa cylindrica in India. Plant Dis. 2003 Sep 1;87(9):11481148.

43. Price JA, Smith J, Simmons A, Fellers J, Rush CM. Multiplex real-time RT-PCR for detection of Wheat streak mosaic virus and Triticum mosaic virus. J Virol Methods. 2010 May;165(2):198-201.

44. Araujo R, Amorim A, Gusmão L. Diversity and specificity of microsatellites within Aspergillus section Fumigati. BMC Microbiol. 2012 Jul 28;12:154. 
45. Leke WN, Mignouna DB, Brown JK, Kvarnheden A. Begomovirus disease complex: emerging threat to vegetable production systems of West and Central Africa. Agriculture \& Food Security. 2015 Jan 21;4(1):1.

46. Rick J, Tsai M-C, Hwang BJ. Biosensors Incorporating Bimetallic Nanoparticles. Nanomaterials (Basel) [Internet]. 2015 Dec 31;6(1). Available from: http://dx.doi.org/10.3390/nano6010005

47. Jayanthi VSPKSA, V.S.P.K. Sankara Aditya Jayanthi, Das AB, Saxena U. Recent advances in biosensor development for the detection of cancer biomarkers [Internet]. Vol. 91, Biosensors and Bioelectronics. 2017. p. 15-23. Available from: http://dx.doi.org/10.1016/j.bios.2016.12.014

48. Thaxton CS, Georganopoulou DG, Mirkin CA. Gold nanoparticle probes for the detection of nucleic acid targets. Clin Chim Acta. 2006 Jan;363(1-2):120-6.

49. Hutter E, Fendler JH. Exploitation of Localized Surface Plasmon Resonance. Adv Mater. 2004;16(19):1685-706.

50. Liz-Marzán LM. Tailoring surface plasmons through the morphology and assembly of metal nanoparticles. Langmuir. 2006 Jan 3;22(1):32-41.

51. Miller SA, Beed FD, Harmon CL. Plant disease diagnostic capabilities and networks. Annu Rev Phytopathol. 2009;47:15-38.

52. Wang T-M, Yang J-T. Visual DNA diagnosis of Tomato yellow leaf curl virus with integrated recombinase polymerase amplification and a gold-nanoparticle probe. Sci Rep. 2019 Oct 22;9(1):15146.

53. Kumar P, Arun V, Lokeswari TS. Cloning of BBTV (Banana Bunchy Top Virus) components and screening of BBTV using functionalized gold nanoparticles. 3 Biotech. 2017 Jul;7(3):225.

54. Dellaporta SL, Wood J, Hicks JB. A plant DNA minipreparation: Version II. Plant Mol Biol Rep. 1983 Sep 1;1(4):19-21.

55. Deng D, McGrath PF, Robinson DJ, Harrison BD. Detection and differentiation of whitefly-transmitted geminiviruses in plants and vector insects by the polymerase chain reaction with degenerate primers. Ann Appl Biol. 1994;125(2):327-36.

56. Lavanya R, Arun V. Standardization of DNA extraction protocol and screening of begomovirus in chilli and tomato plants. J Plant Dis Prot . 2019 May 6;42:265.

57. Zhang X, Servos MR, Liu J. Surface science of DNA adsorption onto citrate-capped gold nanoparticles. Langmuir. 2012 Feb 28;28(8):3896-902.

58. Hill HD, Mirkin CA. The bio-barcode assay for the detection of protein and nucleic acid targets using DTT-induced ligand exchange. Nat Protoc. 2006;1(1):324-36.

59. Fang G, Hammar S, Grumet R. A quick and inexpensive method for removing polysaccharides from plant genomic DNA. Biotechniques. 1992 Jul;13(1):52-4, 56.

60. Wasswa P, Otto B, Maruthi MN, Mukasa SB, Monger W, Gibson RW. First identification of a sweet potato begomovirus (sweepovirus) in Uganda: characterization, detection and distribution. Plant Pathol. 2011 Dec 24;60(6):1030-9. 
61. Kumar Jitendra R. Detection of Gemini virus in Cassava and Differentiation between SLCMV and ICMV by Multiplex PCR. International Journal of Agriculture Sciences. 2018;10(5):5255-9.

62. Saha A, Saha B, Saha D. Molecular detection and partial characterization of a begomovirus causing leaf curl disease of potato in sub-Himalayan West Bengal, India. J Environ Biol. 2014 May;35(3):601-6.

63. Bandaranayake W, Wickramarachchi W. Molecular detection and characterization of begomoviruses associated with cucurbitaceae vegetables in Sri Lanka. Journal of the National [Internet]. 2014; Available from: https://jnsfsl.sljol.info/articles/10.4038/jnsfsr.v42i3.7400/galley/5726/download/

64. Idris AM, Brown JK. Sinaloa Tomato Leaf Curl Geminivirus: Biological and Molecular Evidence for a New Subgroup III Virus. Phytopathology. 1998 Jul;88(7):648-57.

65. Wartig L, Kheyr-Pour A, Noris E, De Kouchkovsky F, Jouanneau F, Gronenborn B, et al. Genetic analysis of the monopartite tomato yellow leaf curl geminivirus: roles of V1, V2, and C2 ORFs in viral pathogenesis. Virology. 1997 Feb 17;228(2):132-40.

66. Harrison BD, Robinson DJ. NATURAL GENOMIC AND ANTIGENIC VARIATION IN WHITEFLYTRANSMITTED GEMINIVIRUSES (BEGOMOVIRUSES). Annu Rev Phytopathol. 1999;37:369-98.

67. Sharma P, Ikegami M. Characterization of signals that dictate nuclear/nucleolar and cytoplasmic shuttling of the capsid protein of Tomato leaf curl Java virus associated with DNA $\beta$ satellite. Virus Res. 2009 Sep 1;144(1):145-53.

68. Brown JK, Idris AM, Torres-Jerez I, Banks GK, Wyatt SD. The core region of the coat protein gene is highly useful for establishing the provisional identification and classification of begomoviruses. Arch Virol. 2001 Aug;146(8):1581-98.

69. Wyatt SD, Brown JK, Others. Detection of subgroup III geminivirus isolates in leaf extracts by degenerate primers and polymerase chain reaction. Phytopathology. 1996;86(12):1288-93.

70. Dharanivasan G, Mohammed Riyaz SU, Michael Immanuel Jesse D, Raja Muthuramalingam T, Rajendran G, Kathiravan K. DNA templated self-assembly of gold nanoparticle clusters in the colorimetric detection of plant viral DNA using a gold nanoparticle conjugated bifunctional oligonucleotide probe. RSC Adv. 2016 Jan 26;6(14):11773-85.

71. Shawky SM, Bald D, Azzazy HME. Direct detection of unamplified hepatitis C virus RNA using unmodified gold nanoparticles. Clin Biochem. 2010 Sep;43(13-14):1163-8.

72. Wilisiani F, Mashiko T, Wang W-Q, Suzuki T, Hartono S, Neriya Y, et al. New recombinant of Tomato leaf curl New Delhi virus infecting melon in Indonesia. J Gen Plant Pathol. 2019 Jul 1;85(4):306-10.

73. Kenyon L, Tsai W-S, Shih S-L, Lee L-M. Emergence and diversity of begomoviruses infecting solanaceous crops in East and Southeast Asia. Virus Res. 2014 Jun 24;186:104-13.

74. Sakata J-J, Shibuya Y, Sharma P, Ikegami M. Strains of a new bipartite begomovirus, pepper yellow leaf curl Indonesia virus, in leaf-curl-diseased tomato and yellow-vein-diseased ageratum in Indonesia. Arch Virol. 2008 Nov 18;153(12):2307-13.

75. Shih SL, Tsai WS, Green SK, Khalid S, Ahmad I, Rezaian MA, et al. Molecular Characterization of Tomato and Chili Leaf Curl Begomoviruses from Pakistan. Plant Dis. 2003 Feb 1;87(2):200-200. 
76. Tahir M, Haider MS, Briddon RW. Chili leaf curl betasatellite is associated with a distinct recombinant begomovirus, Pepper leaf curl Lahore virus, in Capsicum in Pakistan. Virus Res. 2010 Apr;149(1):109-14.

77. Tiendrébéogo F, Lefeuvre P, Hoareau M, Traoré VSE, Barro N, Péréfarres F, et al. Molecular and biological characterization of Pepper yellow vein Mali virus (PepYVMV) isolates associated with pepper yellow vein disease in Burkina Faso. Arch Virol. 2011 Mar 1;156(3):483-7.

78. Zhou Y-C, Noussourou M, Kon T, Rojas MR, Jiang H, Chen L-F, et al. Evidence of local evolution of tomato-infecting begomovirus species in West Africa: characterization of tomato leaf curl Mali virus and tomato yellow leaf crumple virus from Mali. Arch Virol. 2008 Feb 16;153(4):693-706.

79. Kumar RV, Singh AK, Singh AK, Yadav T, Basu S, Kushwaha N, et al. Complexity of begomovirus and betasatellite populations associated with chilli leaf curl disease in India. J Gen Virol. 2015 Oct;96(10):3143-58.

80. Wilisiani F, Tomiyama A, Katoh H, Hartono S, Neriya Y, Nishigawa H, Natsuaki T (2019) Development of a LAMP assay with a portable device for real-time detection of begomoviruses under field conditions. Journal of Virological Methods 265: 71-76

\section{Figures}

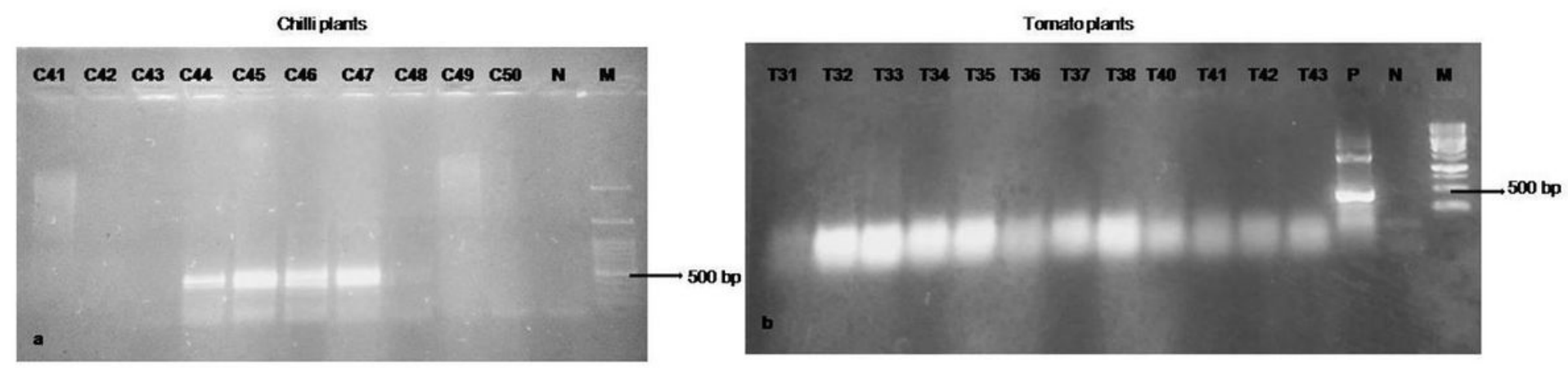

\section{Figure 1}

Screening of plants for the presence of begomovirus by PCR using Deng primers (Deng et al., 1994) a Lanes 1 to 10: Chilli DNA samples C41 to C50; $\mathrm{N}$ - Negative; M - 1 Kb DNA ladder b Lanes 1 to 12: Tomato DNA samples isolated by Dellaporta method; P - Positive Plasmid DNA; N - Negative; M - 1 Kb DNA ladder 


\section{Chilli leaf curl virus clone pTZCCPp3 pre-coat protein (V2) gene, complete cds; and coat protein (V1) gene, partial cds}

GenBank: MH500267.1

\section{FASTA Graphics}

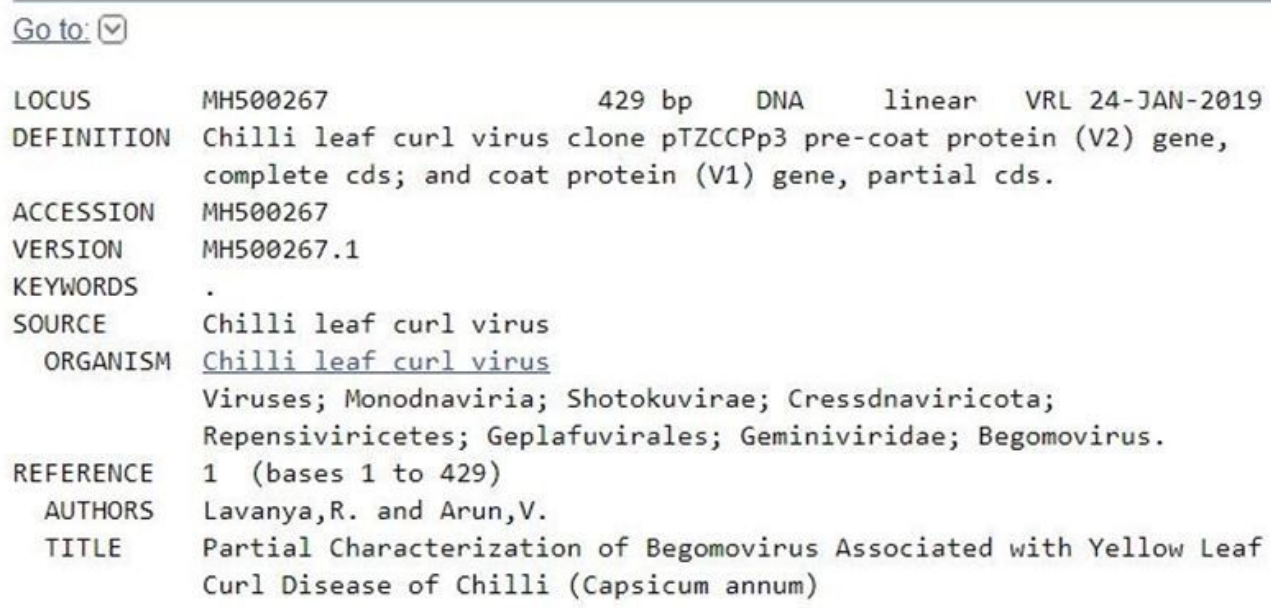

\section{Figure 2}

Chilli leaf curl viral coat protein gene (partial) obtained in this study
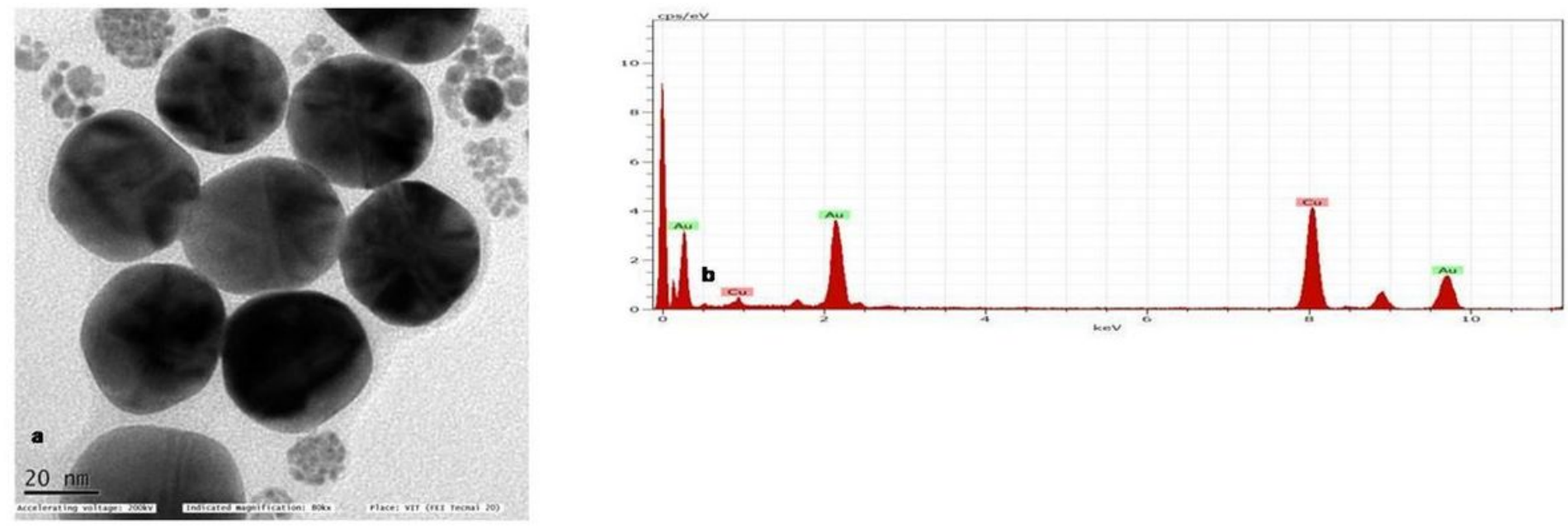

\section{Figure 3}

Microscopic and spectroscopic analysis of AuNPs. a Transmission Electron Micrograph (TEM) of AuNPs.

b Energy Dispersive X-ray (EDX) spectroscopic analysis of synthesized AuNPs 


\section{SZ-100}

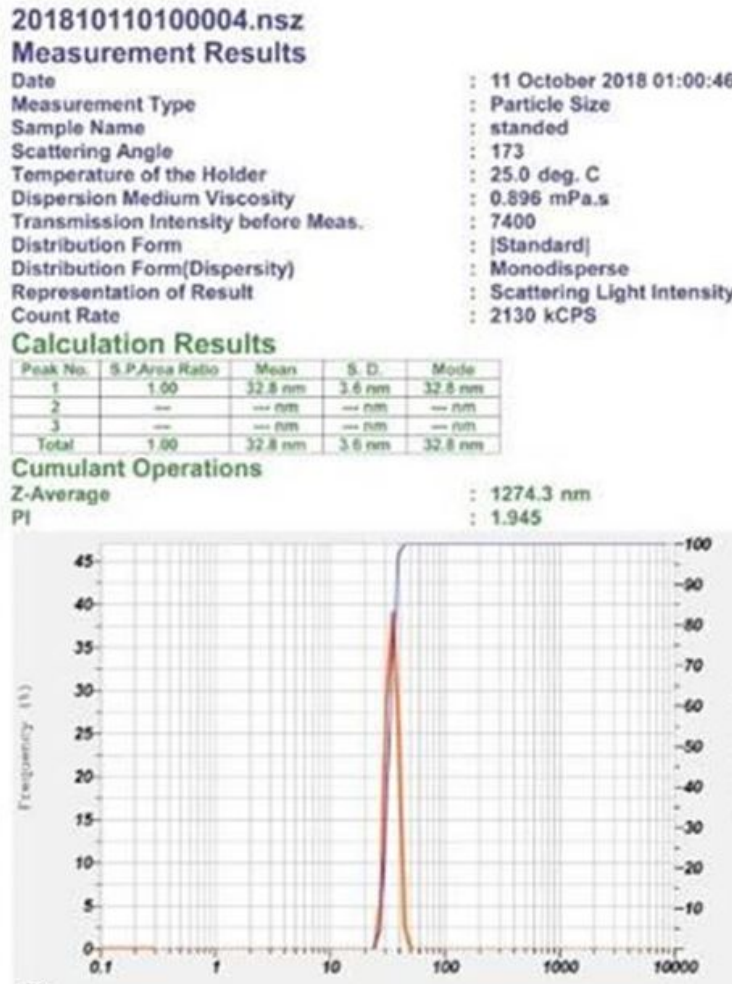

8

Dimeter iom

Hornson
HORIBA

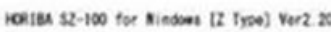

SZ-100

\section{Measurement Results}
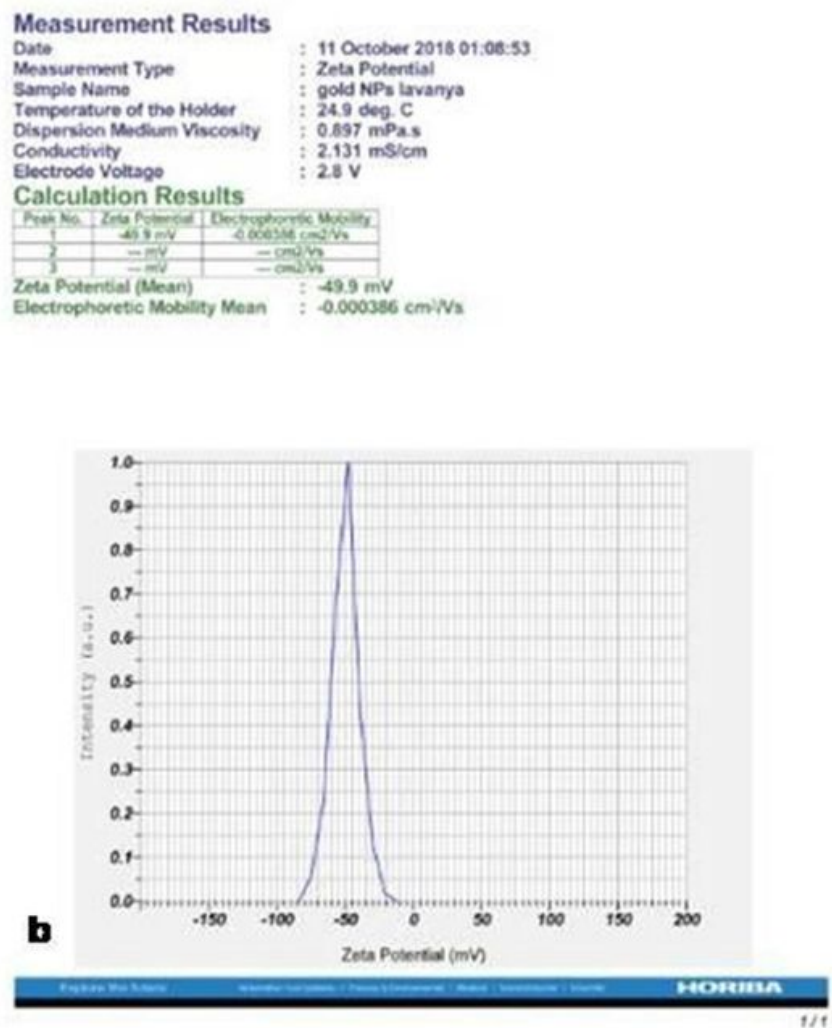

\section{Figure 4}

a Particle size analysis of functionalized AuNPs b Zeta potential of functionalized AuNPs
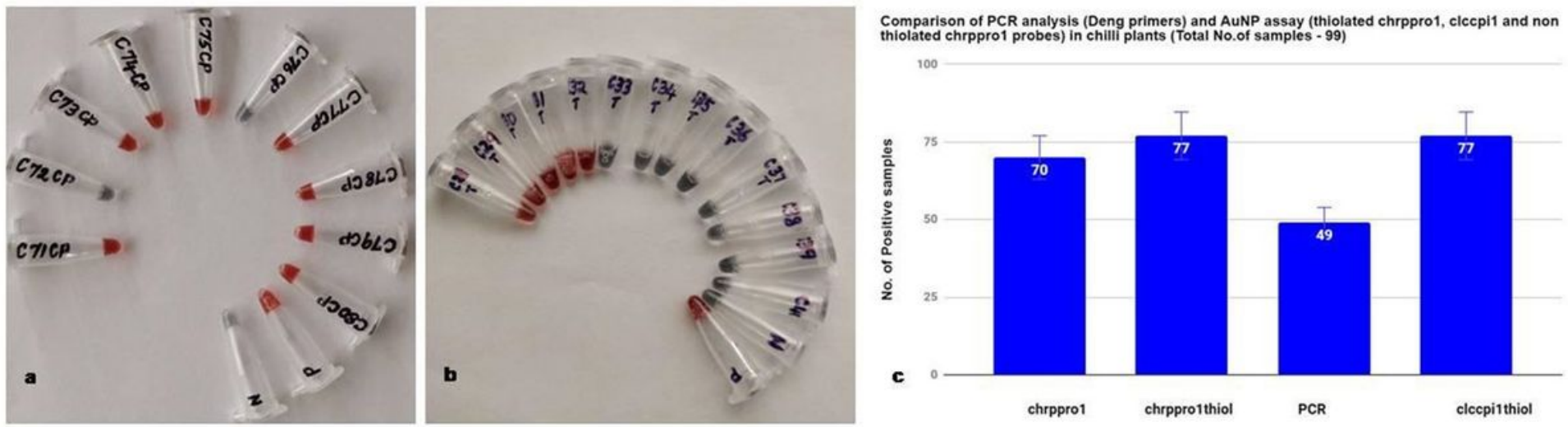

\section{Figure 5}

Detection of begomovirus in chilli samples using functionalized AuNPs a With clccpi1 thiol probe; plant DNA (C71 to C80); positive (P) - plasmid pTZCCPp3; $\mathrm{N}$ - negative b With chrppro1 thiol probe; plant DNA (C28 to C40); positive (P) - PCR positive plant DNA; N negative c Comparison of PCR and AuNP assay with different probes for chilli samples 

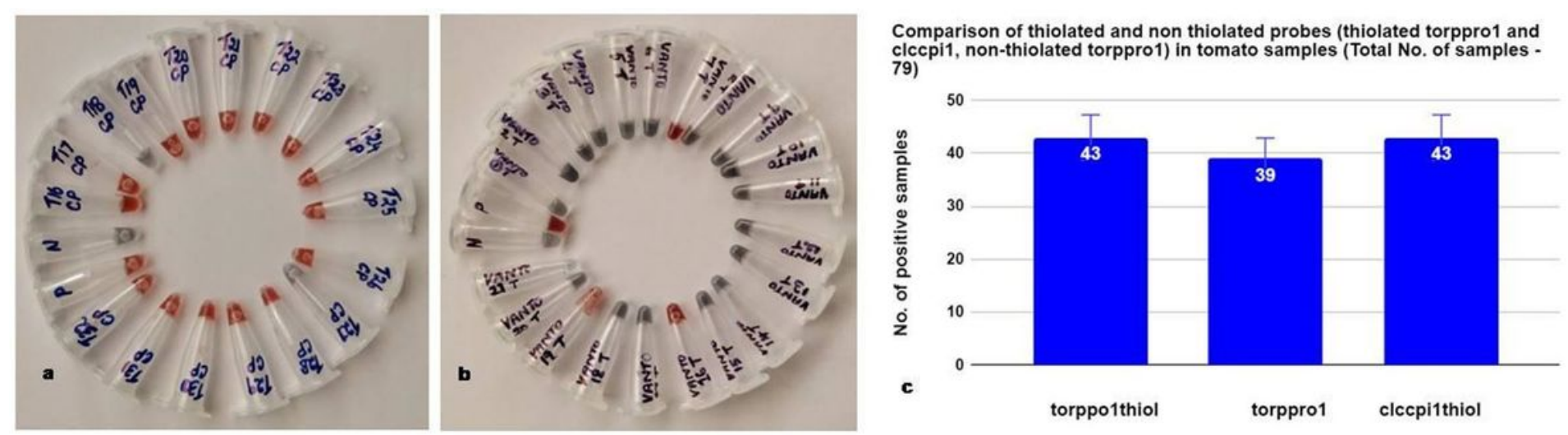

\section{Figure 6}

Detection of begomovirus in tomato plants using functionalized AuNPs a With clccpi1 thiol probe, plant DNA (T16 to T32), positive (P) - plasmid pTZCCPp3, N negative b With torppro1 thiol probe, plant DNA (To1 to To21), positive (P) - PCR positive plant DNA, N negative c Comparison of AuNP assay with different probes for tomato samples
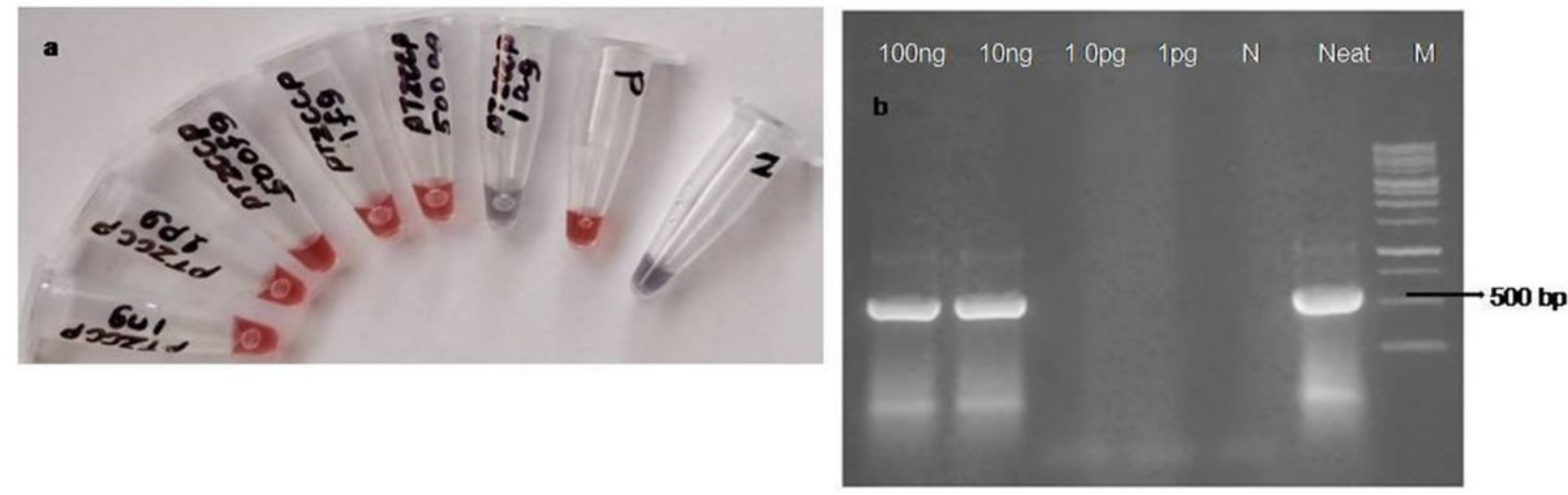

\section{Figure 7}

Comparison of the sensitivity of the AuNP assay and PCR (M13 primers) using different concentrations of plasmid (pTZCCPp3) diluted with Milli Q water. a AuNP assay with clccpi1 thiol probe was able to detect plasmid up to $500 \mathrm{ag} / \mu \mathrm{l}$ b PCR was able to detect plasmid up to $10 \mathrm{ng} / \mu \mathrm{l}$ 

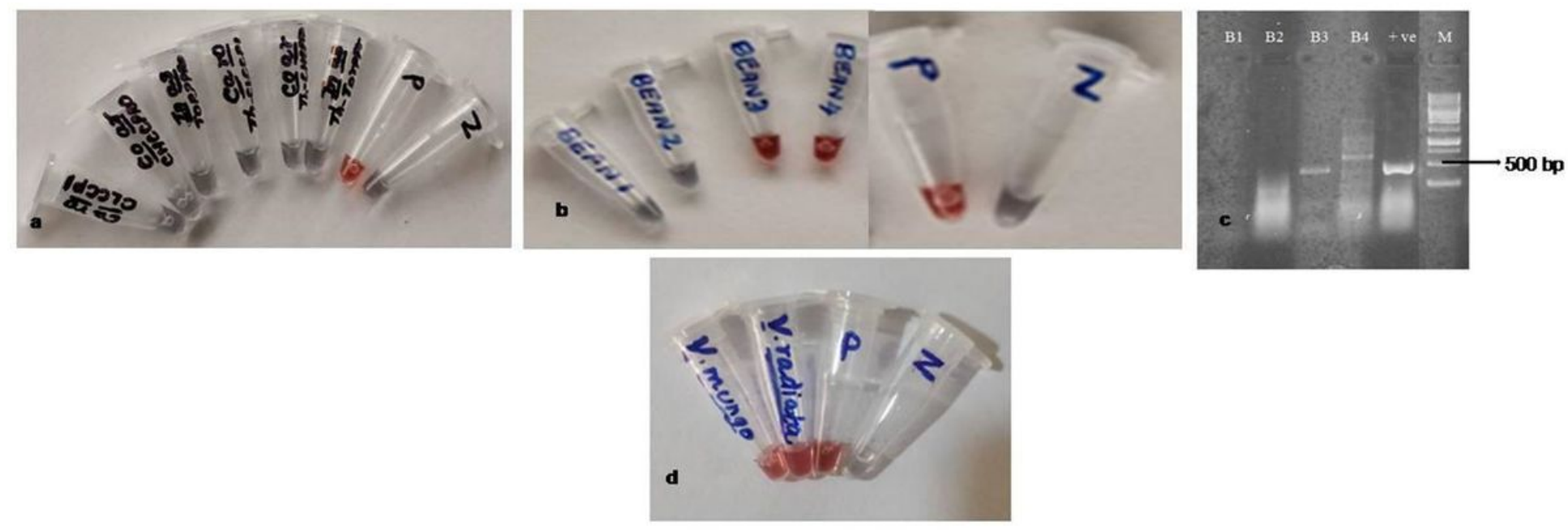

\section{Figure 8}

Specificity and versatility of AuNP assay for the probe - clccpi1 thiol. a Using unrelated plant DNA of three plants I. aspalathoides, P. amboinicus and C. roseus $b$ Using plants belonging to other family (Fabaceae) - P. vulgaris (common bean) that are infected by different begomoviruses $\mathrm{C}$ PCR detection of begomovirus infection in bean plants (B1 to B4) using Deng primers d Screening of begomovirus infected positive samples V. mungo (black gram) and V. radiata (mung bean) belonging to family Fabaceae were procured from TNAU

\section{Supplementary Files}

This is a list of supplementary files associated with this preprint. Click to download.

- Graphicalabstract.jpg 